\title{
Overwinter Survival of Bean Rust Urediniospores in North Dakota
}

\author{
P. L. Gross and J. R. Venette, Department of Plant Pathology, North Dakota State University, Fargo 58105-5012
}

\begin{abstract}
Gross, P. L., and Venette, J. R. 2001. Overwinter survival of bean rust urediniospores in North Dakota. Plant Dis. 85:226-227.

Bean rust (Uromyces appendiculatus) reached epidemic proportions in North Dakota and Minnesota from 1993 to 1996. Although U. appendiculatus is a macrocyclic autoecious rust, neither pycnia nor aecia have been observed in commercial dry bean (Phaseolus vulgaris) in North Dakota fields. The source of initial inoculum is not clearly understood. This study determined the potential for urediniospore survival overwinter. Uredia-bearing bean leaves from artificially inoculated greenhouse-grown plants were kept outside near a field from November to May from 1990 to 1996. Based on bioassays urediniospores survived overwinter, but viability declined over time. Overwinter survival indicates urediniospores may function as initial inoculum.
\end{abstract}

Additional keywords: pustules, teliospores

Dry bean (Phaseolus vulgaris L.) is an important crop in North Dakota. Annual production on approximately 243,000 ha is dominated by pinto and navy varieties. Bean rust, incited by Uromyces appendiculatus (Pers.:Pers.) Unger, reached epidemic proportions from 1993 to 1996. In 1994, yield losses due to bean rust were estimated at $16 \%$ (or $\$ 13.7$ million) and in 1996 , yield losses were $6 \%$, but the economic impact was $\$ 12$ million (J. R.Venette, unpublished data). As recently as the early 1980s, epidemics were more severe when rust infections developed before 10 July. Initial infection is commonly found in areas of fields adjacent to bean fields that were infected the previous year or near sheltered areas of fields where moisture favors prolonged plant wetness.

Initial inoculum has not been clearly established. The fungus is autoecious and macrocyclic. In the field, uredia are converted to telia by mid-September. Teliospores are assumed to overwinter on the soil or in association with bean debris. Pycnia and aecia, indicative of infection by basidiospores from teliospores, were described only once in North Dakota (11), and have been reported as rare in other locations $(10,12)$. Neither pycnia nor aecia have been documented on beans in commercial fields in North Dakota but have been found on volunteer beans in grain fields in North Dakota (11). In 1989, pycnia and aecia were found on volunteer

Corresponding author: Patrick L. Gross E-mail: Patrick_Gross@ndsu.nodak.edu

Accepted for publication 8 November 2000.

Publication no. D-2000-1218-02R

(C) 2001 The American Phytopathological Society pinto beans in four grain and one corn field in Colorado (8).

Urediniospore survival has been proposed in Oregon (5), which has a longer bean growing season and milder winters than the central plains states. In North Dakota, overwinter survival would include a 7-month host-free period. During much of that time, temperatures below freezing may extend the viability of the pathogen.

Urediniospores can survive freezing. Freezing is a common method of preservation, and 2-year survival under controlled conditions has been documented $(4,5,6,7)$. To our knowledge, the survival of urediniospores on bean debris in fields has not been studied in North Dakota, which has the greatest bean production in the United States. Experiments were designed to test the potential for overwinter survival of urediniospores.

\section{MATERIALS AND METHODS}

Production of uredinia. Greenhousegrown pinto beans 'UI-111' or 'Topaz' were inoculated with rust urediniospores collected from naturally infected bean plants. Spores from field-infected plants were dried over calcium sulfate $(8 \mathrm{mesh})$ at $4^{\circ} \mathrm{C}$ for $18 \mathrm{~h}$, then maintained in $1.0 \mathrm{ml}$ cryogenic vials at $15^{\circ} \mathrm{C}$. Beans were grown as single plants in $6.5 \mathrm{~cm}$ square plastic pots filled with potting medium (Sunshine mix no. 1). Ten days after planting in late September, unifoliate leaves at the V1 growth stage (8) were inoculated by spraying a suspension of 10 $\mathrm{ml}$ Soltrol 170 oil carrying $0.03 \mathrm{~g}$ rust spores through an atomizer (3). When the oil had evaporated (within 5 min), plants were wetted with a solution of $0.1 \%$ Tween 20 and were transferred to a humidity chamber ( $+90 \%$ relative humidity, $18^{\circ} \mathrm{C}$ ) for $16 \mathrm{~h}$. Bean plants were then incubated in a greenhouse at $22^{\circ} \mathrm{C}$ for 14 days at which time rust pustules had developed.

Exposure of infected leaves. Uniformly infected leaves, each with approximately 150 pustules, were removed from arbitrarily selected plants and placed four per bag into each of 16 nylon mesh bags, which were stapled shut. Bags were randomly divided into two groups and each group contained a wire mesh basket to provide protection from animals. The wire mesh baskets were attached to a small tree in a shelterbelt or to a wooden post next to a field at the North Dakota State University campus in the third week of October. At each site, one basket was fixed $0.3 \mathrm{~m}$ aboveground and one was placed on the ground. Within the first 10 days of each month a single nylon bag was removed from each wire enclosure, and plant tissue was assayed for viable urediniospores. Weather conditions were monitored by a North Dakota Agricultural Weather Station within $0.5 \mathrm{~km}$ of the site. Identical tests were made each year over a 5-year period.

Assay of plant residue. For the first 3 years of the study, the experimental leaf debris was weighed, crushed, suspended in $0.1 \%$ Tween 20 solution, and sprayed onto unifoliate leaves of 10 susceptible pinto beans within $4 \mathrm{~h}$ of recovery from the exposed mesh bags. Inoculated plants were gently misted with Tween 20 solution and incubated in a moist chamber and in the greenhouse as above. Pustules on each leaf were counted 14 days after transfer to the greenhouse.

Beginning in 1994 recovered material was segregated on separate aluminum foil sheets and conditioned at $4^{\circ} \mathrm{C}$ and relative humidity near $90 \%$ for 7 days in a refrigerator. Conditioned material from each exposure was weighed and ground with mortar and pestle. The crushed material was loaded into a $3 \mathrm{cc}$ syringe, suspended in $1.5 \mathrm{ml}$ Soltrol 170 oil, and thoroughly mixed. The syringe was attached to a Swinney $13 \mathrm{~mm}$ filter holder fitted with a 300 mesh screen. The suspension was forced through the screen and the filtrate was collected in empty gelatin capsules (Lily, no. 00). Each capsule was fitted into an atomizer, and the contents were dispersed onto a group of 10- to 12-day-old susceptible pinto plants ('UI-111' or 'Topaz') grown in a rust-free greenhouse. Each group of plants was placed in a separate humidity chamber and later kept segregated in a greenhouse with growing conditions as previously described. Rust pustules were counted on each leaf within each group as before. 
Table 1. Mean number of uredinia formed on 20 seedling bean leaves inoculated with urediniospores from rusted leaf debris overwintered outside in Fargo, ND

\begin{tabular}{|c|c|c|c|c|c|c|c|}
\hline \multirow[b]{2}{*}{ Year } & \multicolumn{7}{|c|}{ Month } \\
\hline & November & December & January & February & March & April & May \\
\hline 1990 to 1991 & 4 & 12 & 0 & 0 & 8 & 0 & $\mathrm{NT}^{\mathrm{a}}$ \\
\hline 1991 to 1992 & 6 & 25 & 1 & 0 & 0 & 0 & NT \\
\hline 1993 to 1994 & 9 & 35 & 1 & 1 & NT & $100^{\mathrm{b}}$ & NT \\
\hline 1994 to 1995 & $+1,000$ & +900 & 322 & 580 & 45 & 44 & 20 \\
\hline 1995 to 1996 & 101 & 121 & 52 & 140 & 10 & 10 & 13 \\
\hline
\end{tabular}

a Not tested.

b Prior to April 1994, leaf debris was not conditioned before assay, but from April 1994 through May 1996 leaf debris was conditioned at $90 \%$ relative humidity for 7 days at $4^{\circ} \mathrm{C}$ before inoculation of plants.

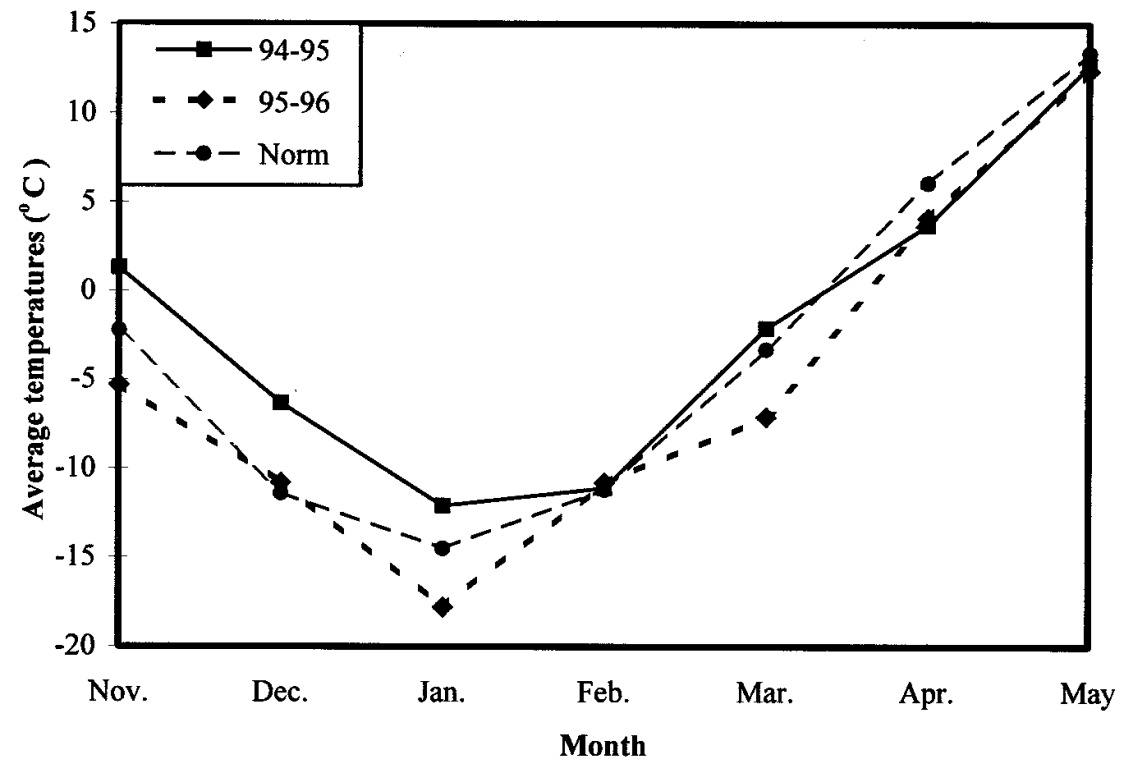

Fig. 1. Winter and spring air temperatures of 1994 to 1995 and 1995 to 1996 compared to 30-year averages (1960 to 1990).

\section{RESULTS AND DISCUSSION}

For all 5 years, differences between survival on the soil surface representing detached debris, and survival above the soil surface representing standing plant residue were not apparent. Therefore data were combined and means calculated for each month. For the first 3 years of the study, the number of uredinia developed on assay plants indicated that urediniospore survival was poor, or lasted only into March. In April 1994, urediniospores were left in the refrigerator for 3 weeks because susceptible test plants had poor germination and had to be replanted. The number of uredinia on assay plants indicated apparent survival increased dramatically over the tests in January and February (Table 1). The difference was interpreted as the result of spore conditioning. For bean and other rust pathogens, conditioning increases urediniospore viability $(2,7)$.

In the 1995 and 1996 tests, conditioned spores were assayed and uredinospores survived into May (Table 1). Rust survival declined over time from November to May. Temperatures were warmer than normal in early winter of 1994 to 1995 and colder than normal for 1995 to 1996 , (Fig. 1) than the 30-year average (1960 to 1990).

The bean season, determined by soil temperatures in the spring and the frostfree period, is approximately May 20 to September 20 in North Dakota. On average, $50 \%$ of the bean crop is planted by May 20, and $50 \%$ of the planted beans emerge by the first week in June (8). May and June are among the wettest months with $13 \%(6.2 \mathrm{~cm})$ of the annual precipitation in May and 19\% (7.2 cm) in June (1). If inoculum survives through May, susceptible host tissue and moisture are available for infection.

Although most uredinia are converted to telia on mature and senescent plant tissue, uredinia are also common on bean plants at or after harvest. We have observed uredinia on field-grown plants into November. These plants had been mechanically damaged, regrew due to late season rains, or were volunteers from shattered pods or from cull beans following harvest. Overwintered urediniospores could contribute to early initiation of disease and also to buildup of races known to attack beans in North Dakota.

\section{LITERATURE CITED}

1. Beard, L. W., Hamlin W. G., et al. 1995 North Dakota Agricultural Statistics. No. 64.

2. Bromfield, K. R. 1964. Cold-induced dormancy and its reversal in uredospores of Puccinia graminis var. tritici. Phytopathology 54:68-74.

3. Browder, L. E. 1971. Pathogenic specialization in cereal rust fungi, especially Puccinia recondita $\mathrm{f}$. $\mathrm{sp}$ tritici: concepts, methods of study and application. U.S. Dep. Agric. Tech. Bull. 1432.

4. Cunningham, J. L. 1973. Longevity of rust spores in liquid nitrogen. Plant Dis. Rep. 57:793-795.

5. Davison, A. D., and Vaughan, E. K. 1963. Longevity of urediospores of race 33 of Uromyces phaseoli var. phaseoli in storage. Phytopathology 53:736-737.

6. Harter, L. L., and Zaumeyer, W. J. 1941. Differentiation of physiologic races of Uromyces phaseoli typia on bean. J. Agric. Res. 62:717-731.

7. Schein, R. D. 1961. Storage viability of bean rust uredospores. Phytopathology 52:653657.

8. Schwartz, H. F., McMillian, M. S., and Vaughn, M. R. 1990. Aecial and pycinial stages of bean rust in Colorado. Plant Dis. 74:80

9. Schneiter, A. A., Grafton, K. F., and Helm, J. L. 1985. Dry Bean Production Handbook. Ext. Bull. A-602 (Rev.) 4 p.

10. Stavely, J. R., and Pastor-Corrales, M. A. 1989. Rust. Pages 159-194 in: H. F. Schwartz and M. A. Pastor-Corrales, eds. Bean Production Problems in the Tropics. Centro Internacional de Agricultura Tropical, Cali, Colombia.

11. Venette, J. R., Olson, B. M., Nayes, J. B. 1978. Bean rust pycia and aecia in North Dakota. Annu. Rept. Bean Improv. Coop. 21:49.

12. Zaumeyer, W. J., and Thomas, H. R. 1957. A monographic study of bean diseases andmethods for their control. U.S. Dep. Agric. Tech. Bull. 868 (Rev.). 